\title{
Immunoreactivity of neoplastic and non- neoplastic monocytoid B lymphocytes for DBA.44 and other antibodies
}

\author{
M Ohsawa, H Kanno, T Machii, K Aozasa
}

\begin{abstract}
Aims-To evaluate the immunoreactivities of neoplastic and non-neoplastic monocytoid B cells (MBC) and compare them with hairy cell leukemia (HCL) and mantle cell lymphoma (MCL).

Methods-An immunohistochemical study of paraffin wax embedded sections was done on surgically resected specimens of spleens with MBC clusters from patients with gastric cancer (14 cases), tonsils (five cases), and lymph node (two cases) showing lymphoid follicular hyperplasia (LFH), submandibular lymph nodes containing MBC in Sjögren's syndrome (one case). Extranodal organs affected by MCL (three cases) and monocytoid B cell lymphoma (MBCL) (seven cases), and spleens from HCL (four cases) were also studied. These specimens were fixed in $10 \%$ formalin and routinely processed for paraffin wax embedding. Fresh spleen specimens from patients with liver cirrhosis (one case) and gastric cancer (seven cases) were snap frozen.
\end{abstract}

Results-Mantle zone lymphocytes were DBA.44, CD74 positive and showed a weaker reaction for CDw75 than marginal zone lymphocytes and MBC, which were almost DBA negative. In neoplastic diseases tumour cells in MCL were DBA.44, CD74, and CDw75 positive. MBCL showed a positive reaction for CD74 and CDw75, but positivity for DBA.44 was observed in only one of seven cases. The HCL specimens, all positive for DBA.44, showed a weaker reaction for CD74 and a stronger reaction for CDw75 than either MCL and MBCL specimens. Conclusion-These results show that mantle zone lymphocytes and MCL more closely matched HCL for reactivity to DBA.44 than MBC and MBCL. Reactivities for DBA.44 and CDw75 were greater in MBCL compared with its nonneoplastic counterpart, $\mathrm{MBC}$.

(F Clin Pathol 1994;47:928-932)

"Monocytoid" cells or "immature sinus histiocytes", present in the lymph nodes of patients with toxoplasmic lymphadenitis, Sjögren's syndrome, or AIDS, are B cell in nature, and termed monocytoid B cells (MBC).$^{1-4}$ Our recent study showed that $\mathrm{MBC}$ occur in the spleens of older patients with gastric cancer ${ }^{5}$ and extranodal organs affected by auto- immune disorders, such as Hashimito's thyroiditis. ${ }^{6}$ A malignant counterpart of $\mathrm{MBC}$ has subsequently been recognised-monocytoid B cell lymphoma (MBCL). ${ }^{7}$

The B cell character of hairy cell leukemia (HCL) has been well established by immunological and immunogenetic studies. ${ }^{89}$ However, the normal counterpart of HCL cells and its stage in the continuum of $B$ cell differentiation remains unknown. HCL cells characteristically express an antigen (CD11c) usually found on monocytes/macrophages recognised by Leu-M5, together with B cell antigens. ${ }^{10}$ Immunophenotypic similarities between HCL cells and MBC have been reported. ${ }^{11} 12$

Monoclonal antibody DBA.44, which is raised against a diffuse large cell lymphoma cell line in normal Balb/C mice, reacts with a subpopulation of B lymphocytes in the mantle zone of lymphoid follicles. ${ }^{13}$ Within the group of low grade B cell lymphomas DBA.44 reacted principally with HCL. In this study the immunoreactivities of neoplastic and nonneoplastic MBC to DBA.44 and other antibodies were evaluated and compared with HCL and mantle cell lymphoma (MCL).

\section{Methods}

Surgically resected spleens from patients with gastric cancer $(n=14)$, tonsil of lymphoid follicular hyperplasia $(\mathrm{LFH}) \quad(\mathrm{n}=5)$, lymph nodes of LFH $(n=2)$, submandibular lymph node of Sjögren's syndrome $(n=1)$, extranodal organs affected by MCL $(n=3)$ and MBCL $(n=7)$, and spleens from HCL ( $n=$ 4) were investigated. The sex ratio and median age of patients was as follows: gastric cancer, 2.3:1 and 49 years; LFH of tonsil, 3:1 and 34 years; LFH of lymph nodes, 1:1 and 28 years; Sjögren's syndrome, all female and aged 43 years; MCL, 1:2 and 53 years; MBCL, all female and aged 53 years; and HCL, 3:1 and 49 years, respectively.

All patients with HCL presented with severe splenomegaly, absent or only a mild superficial lymphadenopathy, and circulating leukaemic cells with a hairy appearance as detected by phase contrast microscopy. Immunohistochemical staining showed that the leukaemic cells were acid phosphatase positive because they were resistant to tartrate. Immunologically, these cells had surface immunoglobulins and were positive for CD11c, CD20, and CD25. Specimens were fixed in $10 \%$ formalin and routinely processed for paraffin wax embedding. Sections, cut at
Department of Pathology, Osaka Univesity School of Medicine, 2-2 Yamakaoka, Suita, Osaka 565, Japan Accepted for publication 13 April 1994 
Table 1 Antibody panel

\begin{tabular}{lll}
\hline Antibody & Primary immunoreactivity & Source \\
\hline $\begin{array}{l}\text { Frozen sections } \\
\text { CD5 (Leu1) }\end{array}$ & T cell, mature B cells & \\
CD11c (LeuM5) & Monocytes, granulocytes, hairy cell leukemia & Beckton Dickinson (Mountain \\
View, California) \\
CD24 (BA-1) & Mantle zone cells, granulocytes & Beckton Dickinson \\
DBA.44 & Mantle zone cells, some immunoblasts, hairy cell & Hybritech, Hialeah, Florida \\
& leukemia & Dakopatts (Copenhagen) \\
Paraffin wax sections & & \\
CD3 & T cells & \\
CD15 (LeuM1) & Monocytes, myeloid cells, some epithelial cells & Dakopatts \\
CD20 (Mx-PanB) & B cells & Beckton Dickinson \\
CD43 (MT1) & T cells & Kyowa Medex (Tokyo) \\
CD45RA (4KB5) & B cells, monocytes & Bio-Science (Emmenbrucke) \\
CD45RO (UCHL-1) & T cells & Dakopatts \\
CD74 (LN2) & B cells, interdigitating reticulum cells, Reed-Sternberg cells & Dakopatts \\
CDw75 (LN1) & Germinal centre cells & Techniclone \\
MB-1 & B cells & Bio-Science \\
DBA.44 & Mantle zone cells, hairy cell leukemia & Dakopatts \\
CD68 (KP-1) & Monocytes, granulocytes & Dakopatts \\
CD68 (PGM1) & Monocytes & Dakopatts \\
EMA & Epithelial cells & Dakopatts \\
S-100 & Langerhans' cells & Dakopatts \\
\hline
\end{tabular}

$4 \mu \mathrm{m}$, were stained with haematoxylin and eosin and immunoperoxidase (avidin biotin complex (ABC) method). Fresh spleen specimens from patients with liver cirrhosis (one case) and gastric cancer (seven cases) were snap frozen in liquid nitrogen $\left(-180^{\circ} \mathrm{C}\right)$ and stored at $-80^{\circ} \mathrm{C}$ until use for immunohistochemistry. The monoclonal antibodies used in this study are listed in table 1 . The effect of treatment on tissue sections by microwave oven heating (five minutes) was estimated.

\section{Results}

The results of the immunohistochemical study of reactive states are summarised in table 2 . In the frozen and paraffin wax embedded sections of spleen, mantle zone lymphocytes showed a stronger reaction for DBA.44 than parafollicular cells. Recently, we reported the occurrence of $\mathrm{MBC}$ in the spleen of elderly patients with gastric cancer. ${ }^{5}$ All the paraffin wax embedded spleens from 14 patients with gastric cancer contained clusters of monocytoid B cells, which were completely non-reactive with DBA.44 but were positive for CD20, MB-1, CD45RA, CD74, CDw75, and negative for CD43, CD45RO, CD15, CD68, and epithelial membrane antigen (EMA) (fig 1). In the tonsil and lymph nodes showing LFH, positively reacting cells for DBA.44 were exclusively found in the mantle zone, which were $\mathrm{CD} 20+$, MB-1+, CD45RA+, CD74+, CDw75-. In one case of LFH of tonsil many small cleaved cells, together with non-cleaved cells in the germinal centres, positively stained for DBA.44. Monocytoid cells appearing in the lymph node of Siögren's syndrome were DBA.44-, CD20+, MB-1+, CD74+, CDw75+. Proliferating cells in MCL were positive for DBA.44, though a few cells were positive in one case and CD20+, MB-1+, CD45RA+, CD74+, CDw75+ in all cases. The intensity of staining for DBA.44 in MCL was similar to that in mantle zone lymphocytes, but was rather weaker than that in HCL.

Proliferating cells in one of seven cases of MBCL showed a positive reactivity for DBA.44 and were CD20+, $\mathrm{MB}-1+$, DF45RA+, CD74+, and CDw75+ (fig 2). The microwave heating of tissue sections strengthened the intensity of the positive reaction, though the number of positive cases for DBA.44 did not increase. All cases of HCL reacted positively for DBA.44 and were positive for CD20, MB-1, and CD45RA (fig 3). The reactivity of the proliferating cells in HCL for CD74 was weaker but stronger for CDw75 than those of MCL and MBCL.

Table 2 Results of immunohistochemistry in reactive states

\begin{tabular}{|c|c|c|c|}
\hline \multirow[b]{2}{*}{ Material } & \multicolumn{3}{|l|}{ Immunoreactivities of lymphoid calls } \\
\hline & Mantle zone & Marginal zone & Monocytoid cells \\
\hline $\begin{array}{l}\text { Fresh frozen sections } \\
\text { Spleen of gastric cancer }(\mathrm{n}=7)\end{array}$ & 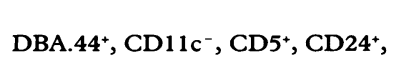 & DBA. $44^{+}, \mathrm{CD} 11 \mathrm{c}^{-}, \mathrm{CD} 5^{-}, \mathrm{CD}^{2} 4^{+}$ & \\
\hline $\begin{array}{l}\text { Paraffin wax sections } \\
\text { Spleen of gastric cancer } \quad(n=14)\end{array}$ & $\begin{array}{l}\text { Numerous DBA.44+ } \\
\text { CD20 }{ }^{+}, \mathrm{MB}^{+} \mathrm{1}^{+}, \mathrm{CD}^{+} \mathrm{R} \mathrm{RA}^{+}, \mathrm{CD}^{+} \\
\mathrm{CDw}^{+} 5^{-}, \mathrm{CD}^{+} 3^{-}, \mathrm{CD} 45 \mathrm{RO}^{-}\end{array}$ & $\begin{array}{l}\text { A few DBA+ cells } \\
\text { CD20 } 20^{+}, \mathrm{MB}^{+} 1^{+}, \mathrm{CD} 45 \mathrm{RA}^{+}, \mathrm{CD}^{+} 4^{+} \\
\mathrm{CDw}^{+} 5^{+}, \mathrm{CD}^{+} 3^{-}, \mathrm{CD} 45 \mathrm{RO}^{-}\end{array}$ & 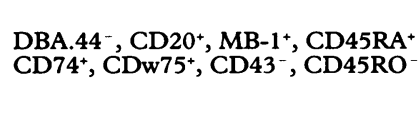 \\
\hline $\begin{array}{l}\text { LFH of tonsil and lymph node } \\
\quad(n=7)\end{array}$ & $\begin{array}{l}\text { DBA.44+ } \\
\text { CD20 } 0^{+}, \mathrm{MB}^{+} 1^{+}, \mathrm{CD}^{2} 5 \mathrm{RA}^{+}, \mathrm{CD}^{+} 4^{+} \\
\text {CDw75 }\end{array}$ & & \\
\hline $\begin{array}{l}\text { Monocytoid cells in Sjögren's } \\
\text { syndrome }(n=1)\end{array}$ & $\begin{array}{l}\text { DBA.44- } \\
\text { CD20 } 0^{+}, \mathrm{MB}^{+} 1^{+}, \mathrm{CD}^{+} 5 \mathrm{RA}^{+}, \mathrm{CD}^{+} \\
\mathrm{CDW}^{+} 5^{-}, \mathrm{CD}^{-} 3^{-}, \mathrm{CD}^{\prime} 5 \mathrm{RO}^{-}\end{array}$ & & 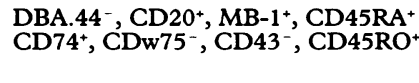 \\
\hline
\end{tabular}


Figure 1 Monocytoid cells near the sheath artery of the spleen $(A)$ haematoxylin and eosin. Monocytoid cells showing a positive reaction for $C D 20(B)$, but not for $D B A .44(C)(A B C$ method).

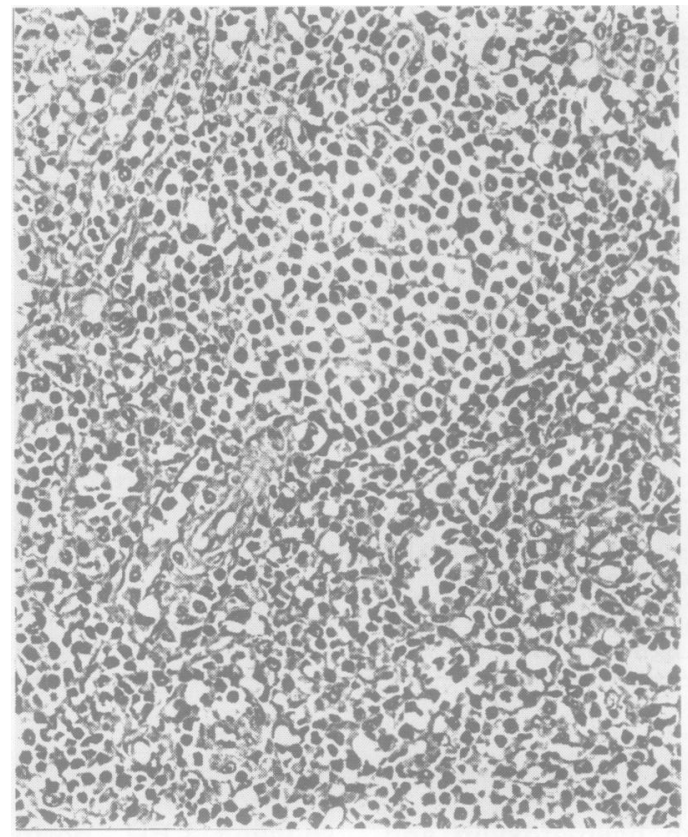

(A)

(B)
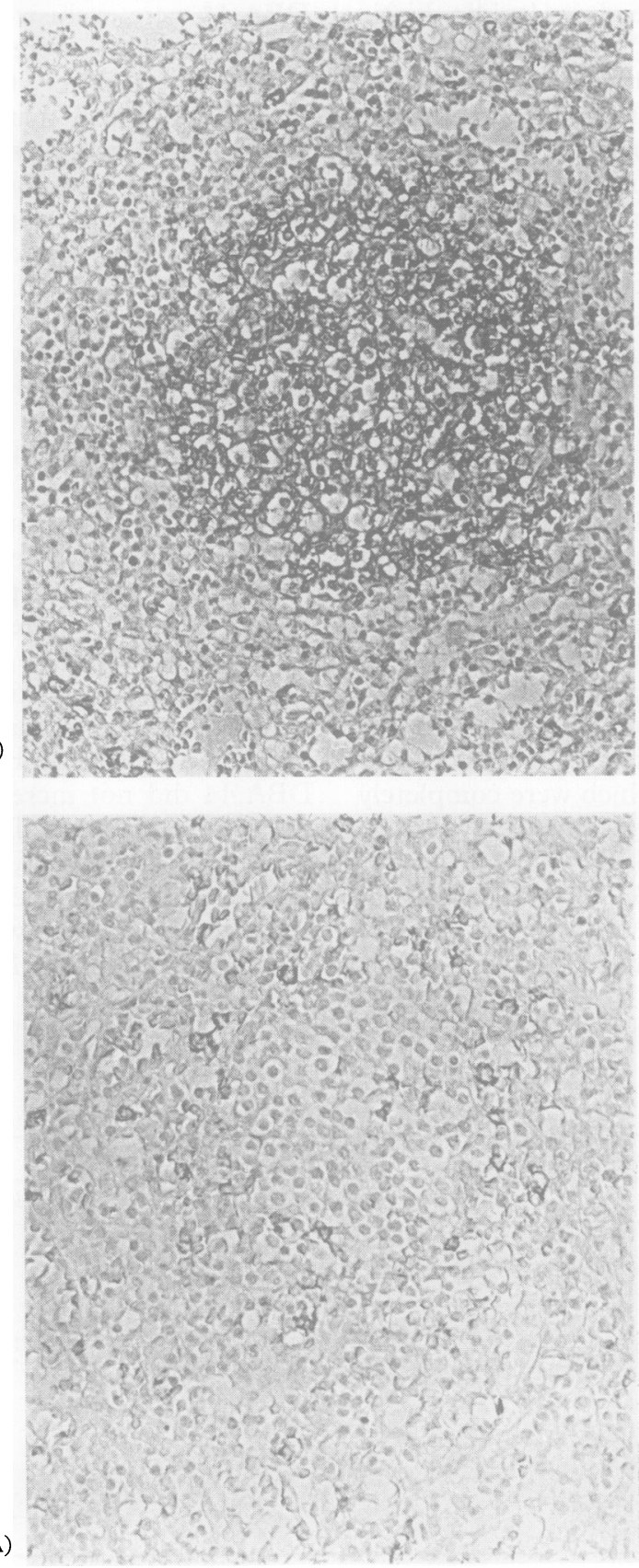

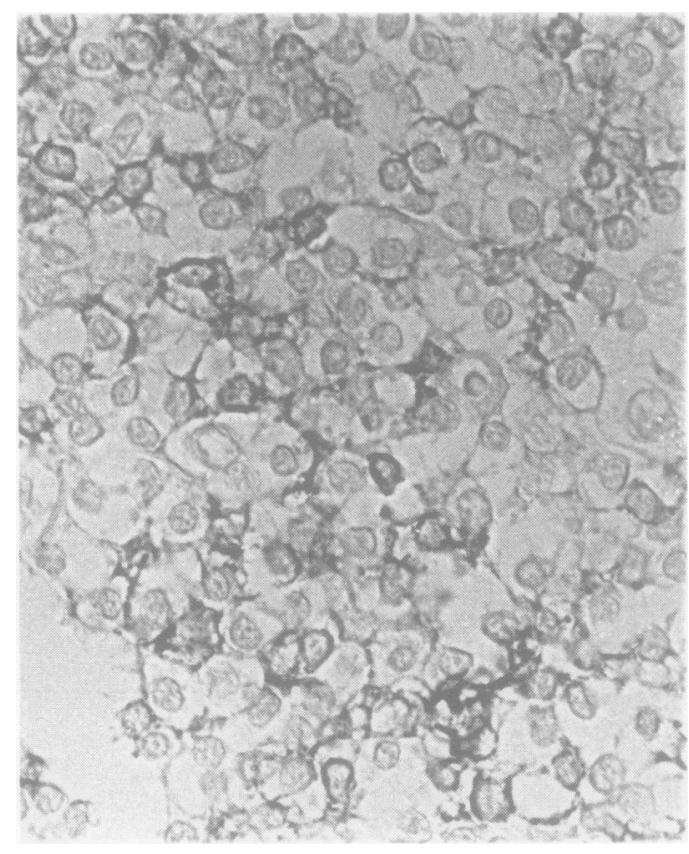

Figure 2 Several cells in monocytoid $B$ cell lymphoma showing surface staining for $D B A .44$ ( $A B C$ method).

\section{Discussion}

Morphological similarities between HCL cells and $\mathrm{MBC}$ and its neoplastic counterpart MBCL have promoted several immunological and immunohistochemical comparisons of these cells. ${ }^{.1012}$ Traweek et al reported that HCL was CD5-, CD3-, CD2-, CD19+, $\mathrm{CD} 20+, \mathrm{CD} 11 \mathrm{c}+, \mathrm{CD} 25+$, and $\mathrm{PCA}-1+.{ }^{1+}$ Except for CD25(Tac) negativity, MBCL showed a similar pattern of reactivity to HCL. ${ }^{11+}$ The circulating MBCL cells exhibited strong acid phosphatase activity that was tartrate sensitive, which does not occur in HCL cells. In paraffin wax sections Stroup and Sheibani reported similar reactivities between HCL and MBCL cells: CD45RA+, CD20+, CDw75+, CD74+, LN3+, MB2+, CD45RO - , CD43-, and CD15-. ${ }^{12}$ These authors suggested that the origin of MBCL is a site closely adjacent to the origin of HCL. ${ }^{12}$ The present immunohistochemical findings in MBCL and HCL are in general agreement with those of previous studies, which indicate positivity for CD20, MB-1, CD45RA, CD74, and CDw75, and negativity for monoclonal antibodies for macrophages and $\mathrm{T}$ lymphocytes. Reactivity for CD74 was rather stronger in MBCL cells than in HCL cells.

The monoclonal antibody DBA.44 is active on paraffin wax embedded specimens and reacts with HCL cells. ${ }^{13}$ Indeed, the proliferating cells in all our cases of HCL stained positively for DBA.44. Recently, Hounieu et al reported that DBA.44 showed the strongest membrane staining in the tumour cells of centroblastic, immunoblastic, and MBC type among cases of node-based lymphomas. ${ }^{15}$ However, only one of seven cases of MBCL in the present study was reactive with DBA.44. Buffered formalin and Bouin's solution were 
Figure 3 (A) Spleen invaded by hairy cell leukemia haematoxylin and eosin. (B) Hairy cell leukemia cells show distinct surface staining for $D B A .44$ ( $A B C$ method).

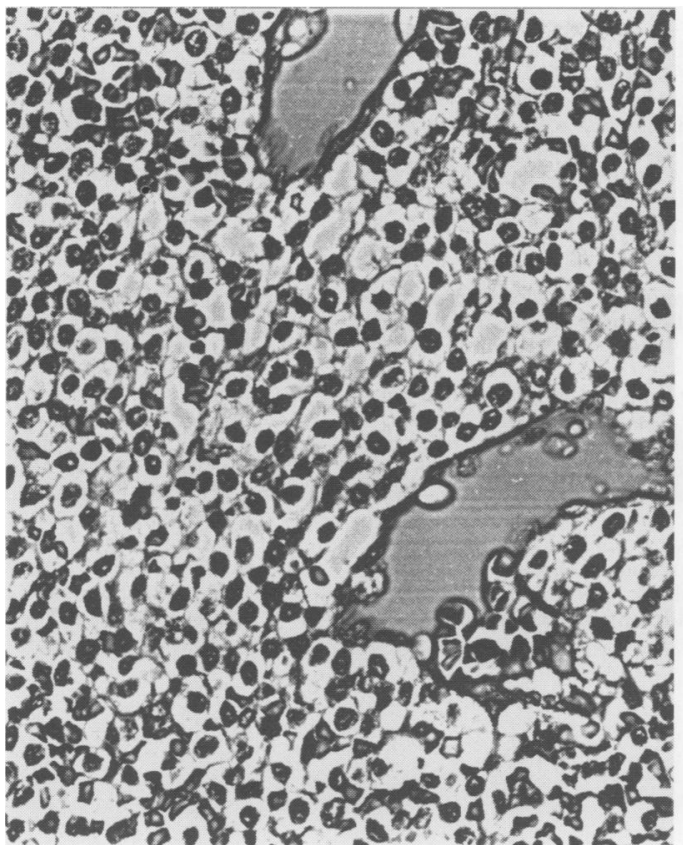

(A)

reported to be the optimal fixatives for DBA.44 staining. ${ }^{15}$ The decreased staining propensity of our cases of MBCL might have been attributable to the type of fixative used$10 \%$ formalin.

All cases of MCL were positive for DBA.44. This antibody is known to be reactive with mantle zone lymphocytes, the normal counterpart of MCL. However, the immunoreactivities of MCL (CD5+, CD11c-) were quite different from those of $\mathrm{MBCL}$ and HCL (CD5-, CD11ct). ${ }^{14}$ In LFH of lymph node and tonsil DBA.44 had its strongest reaction for mantle zone lymphocytes. The MBC in lymph nodes of toxoplasmic lymphadenitis and HIV associated lymphadenitis have been reported to show weak positive staining for DBA.44. ${ }^{15}$ In the present study the MBC in lymph nodes affected by Sjögren's syndrome were not reactive with DBA.44, which might also have been caused by decreased staining propensity due to $10 \%$ formalin fixation.

There have been suggestions that $\mathrm{HCL}$ might originate from the splenic marginal zone, ${ }^{1617}$ but a normal counterpart of the HCL cell has not yet been substantiated. On frozen sections, the marginal zone lymphocytes in the spleen were not reactive with CD11c and CD25 (Tac), ${ }^{18}$ but these were positive in HCL specimens. Some studies have suggested that marginal zone cells occur in the lymph node, ${ }^{19}$ but others refute this. In the present immunohistochemical study on frozen sections of spleen the lymphocytes in the mantle zone were DB.1.44+, CD11c-, $\mathrm{CD} 5+, \mathrm{CD} 24+$ and in the marginal zone were DBA.44+, CD11c-, CD5 - , CD24+. In the paraffin wax sections numerous cells positive for DBA.44 were found in the mantle zone but only a few DBA.44 positive cells in the marginal zone. These findings agree with those of the previous report. ${ }^{15}$

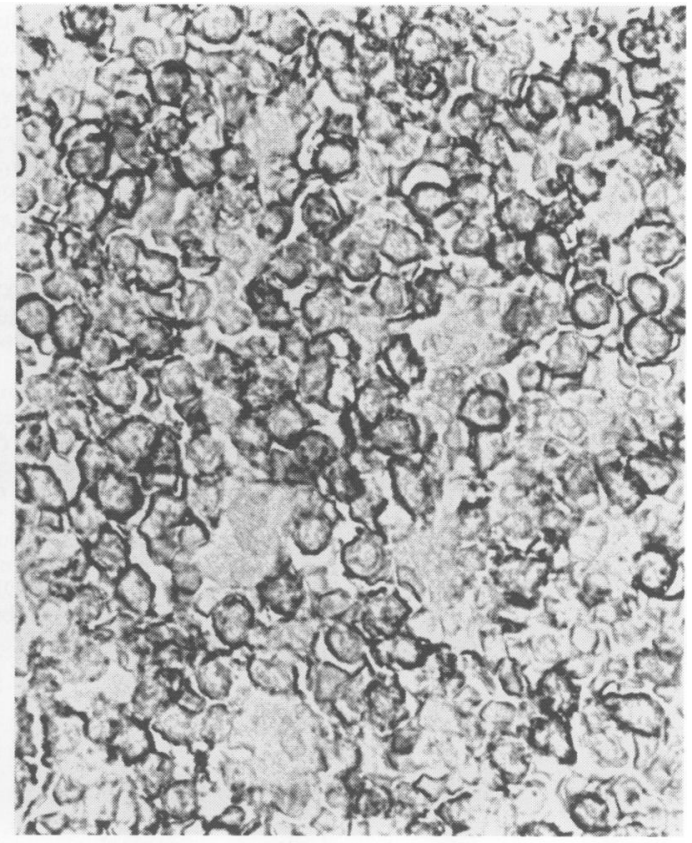

(B)

Our recent study of the spleen in patients with gastric cancer showed the presence of $\mathrm{MBC}$, especially in older patients. ${ }^{6} \mathrm{We}$ discussed the possibility that $\mathrm{MBC}$ in the spleen could be a non-neoplastic counterpart of HCL. However, the MBC observed in the spleens of the present 14 patients with gastric cancer did not react positively for DBA.44.

In conclusion, this study has shown that DBA.44 reacted more strongly with MCL than MBCL. Non-neoplastic MBC were usually negative for DBA.44, but a positive reaction was seen in neoplastic MBC(MBCL), suggesting an increased reactivity for neoplastic cells.

We thank Professor Edward $H$ Cooper for help with the English of the manuscript and Miss $Y$ Matsumoto for typing it. This work was supported in part by a Grant-in-Aid for Cancer Research (4-5) from the Ministry of Health and Welfare and grant from the Ministry of Education, Science and Culture (05152111), Japan.

We are also grateful to the following clinicians for allowing us to study their cases: Dr Takashi Kageyama (Osaka Medical College) Dr Masako Yasuyam (Tokyo Women's Medical College) Dr Masako Yasuyama (Tokyo Women's Medical Hospital), and Dr Hiroyuki Ada (Kawasaki Medical School).

1 Sheinbani K, Fritz RM, Winberg CD, Burke JS, Rappaport H. "Monocytoid" cells in reactive follicular hyperplasia with and without multifocal histiocytic reactions: an immunohistochemical study of 21 cases including suspected cases of toxoplasmic lymphadenitis. $A m \mathcal{F}$ ing suspected cases of toxoplas

2 Sohn CC, Sheibani K, Winberg CD, Rappaport $H$. Monocytoid B lymphocytes: their relation to the patterns of the acquired immunodeficiency syndrome (AIDS) and AIDS-related lymphadnopathy. Hum Pathol 1985; 16:979-85.

3 Stein H, Lennert K, Mason DY, Liangru S, Ziegler A. Immature sinus histiocytosis. Their identification as a novel B-cell population. Am $\mathcal{F}$ Pathol 1984;117:44-52.

4 Van den Oord JJ, de Wolf-Peeters C, De Vos R, Desmet VJ. Immature sinus histiocytosis. Light and electron microscopic features, immunologic phenotypes and relamicroscopic features, immunologic phenotypes and relationship with margin

5 Aozasa K, Ohsawa M, Horiuchi K, Mishima K, Kawano $\mathrm{K}$, Ito N. The occurrence of monocytoid B-lymphocytes in the spleens of patients with gastric cancer. Mod Pathol 1993;6:717-20.

6 Aozasa K, Ohsawa M, Horiuchi K, Saeki K, Katayama S, Matsuzuka $F$, et al. The occurrence of monocytoid Blymphocytes in autoimmune disorders. Mod Pathol 1993;6: 121-4. 
7 Sheibani K, Sohn CC, Burke JS, Winberg CD, Wu AM, Rappaport H. Monocytoid B-cell lymphoma: a novel Bcell neoplasm. Am f Pathol 1986;124:310-18.

8 Jansen J, LeBien TW, Kersey JH. The phenotype of the neoplastic cells of hairy cell leukemia studied with monoclonal antibodies. Blood 1982;59:609-14.

9 Korsmeyer SJ, Greene WC, Cossman J, Hsu S-M, Jensen $J P$, Neckers LM, et al. Rearrangement and expression of immunoglobulin genes and expression of Tac antigen in hairy cell leukemia. Proc Natl Acad Sci USA 1983; 80:4522-6.

10 Schwarting $\mathrm{R}$, Stein $\mathrm{H}$, Wang $\mathrm{CY}$. The monoclonal antibodies $\alpha$ S-HCL1 $(\alpha$ Leu-14) and $\alpha$ S-HCL $(\alpha$ Leu-M5 allow the diagnosis of hairy cell leukemia. Blood 1985;65:974-83.

11 Burke JS, Sheibani K. Hairy cells and monocytoid B-lymphocytes: are they related? Leukemia 1987;1:298-300.

12 Stroup RM, Sheibani K: Antigen phenotypes of hairy cell leukemia and monocytoid B-cell lymphoma: An immunohistochemical evaluation of 66 cases. Hum Pathol 1992;23:172-7.

13 Al Saati T, Caspar S, Brousset $P$, Chittal S, Caveriviere $P$ Hounieu antibodies (DBB.42, DBA.44, DNA.7, and DND.53) reactive on paraffin-embedded tissues with a new B-lym- phoma cell line grafted into a thymic nude mice. Blood 1989; 74:2476-85.

14 Traweek ST, Sheibani K, Winberg CD, Mena RR, Wu AM, Rappaport H. Monocytoid B-cell lymphoma: its evolution and relationship to other low-grade B-cell neoplasms. Blood 1989;73:573-8.

15 Hounieu H, Chittal SM, Al Saati T, Mascarel A, Sabattini E, Pileri S, et al. Hairy cell leukemia. Diagnosis of bone marrow involvement in paraffin-embedded sections with monoclonal antibody DBA.44. Am F Clin Pathol 1992; 98:26-33.

$16 \mathrm{Hsu}$ S-M. Phenotypic expression of B lymphocytes. III. Marginal zone B cells in the spleen are characterized by the expression of Tac and alkaline phosphatase. $f$ Immunol 1985;135:123-30.

17 Van den Oord JJ, de Wolf-Peeters C, Desmet VJ. Hairy cell leukemia: a B-lymphocytic disorder derived from splenic maroinal zone lymphocytes? Blut 1985:50:191-4.

18 Van Krieken JHJM, Von Schilling C, Kluin PM, Lennert $\mathrm{K}$. Splenic marginal zone lymphocytes and related cells in the lymph node: A morphologic and immunohistoin the lymph node: A morphologic and im

19 Van den Oord JJ, De Wolf-Peeters C, Desmet VJ. The marginal zone in human reactive lymph node. $\mathrm{Am} \mathcal{F} \mathrm{Clin}$ Pathol 1986;86:475-9. 
Area Network such as the Internet or CompuServe, users will be able to harness the power of the pathology information explosion effortlessly and focus it precisely on the generation of their reports.

The project is still recruiting and so any pathologist in the UK or elsewhere who is interested in contributing, is welcome to contact the author by post or E-mail (CompuServe 100255,2131).

I read with interest the paper by ...

In his letter ${ }^{1}$ dealing with letters that begin "I read with interest the paper by..." (IRWITPB) Dr O'Briain should have addressed the authors' reply that so frequently starts, "We thank Bloggs for his/her interest in our paper" (WTBFHIIOP). What the authors of such letters probably mean is, "Trust Bloggs to point out that he/she published a larger series than ours 10 years ago" or "Damn Bloggs for noticing that our p values are out by a factor of 10 ".

Over the years, I have noticed that it is uncommon for writers of WTBFHIIOP letters ever to admit honestly their mistakes even when these are pointed out to them in unambiguous terms, preferring to deny, obfuscate, or side-step their errors. Perhaps the problem lies with the fact that letters and authors' replies are not subject to peer review, merely to the perfunctionary scrutiny of an over-worked editor. Perhaps that is how this one got through or am I to expect an ITWFHIIML reply?

$$
\begin{array}{r}
\text { D H WRIGHT } \\
\text { University Department of Pathology, } \\
\text { Southampton General Hospital, } \\
\text { Southampton SO16 6YD }
\end{array}
$$

1 O'Brien DS. I read with interest the paper by ... [letter]. $\mathcal{F}$ Clin Pathol 1994;47:868.

\section{Notices}

\section{The Royal Society of Health}

presents the following courses

\section{Care at Home and Quality of Life} (CH411)

Date: Tuesday, 29 November 1994

Venue: Hotel Ibis, Ladywell Walk, Birmingham B5 4ST

Fee: To be announced

\section{Care at Home and Quality of Life} (CH412)

Date: Tuesday, 13 December 1994

Venue: Regent's College, Regents Park London NW1 4NS

Fee: To be announced

For further information, please contact: Anne Faichney,

Conference Department,

The Royal Society of Health,

RSH House, 38A St George's Drive,

London SW1V 4BH

(Tel: 071630 0121; fax: 071976 6847).

\section{Briançon Congrès of Dermatopathology \\ 6-10 February 1995}

Parc Hotel, Briançon, France

The programme includes slide seminars in dermatopathology as well as case presentations and discussions. Seminars will be given by Dr Jeanine Wéchsler of Paris and Dr Lorenzo Cerroni of Graz. Other seminars will be given by British pathologists. Delegates may also submit cases for presentation and discussion. In addition to interesting and difficult cases there will be a special prize for "The Best Mistake" presented in the special session devoted to this interesting phenomenon in diagnostic histopathology. The week will be suitable for 20 cognate points for CME. This meeting offers an opportunity to meet in the pleasant atmosphere of "the highest fortified town in Europe", in the sunny southern Alps. Delegates will attend from many countries in Europe.

Apply to: Dr N Kirkham, P.O. Box 334, Histopathology Department, Royal Sussex County Hospital, Brighton BN2 5BG. Tel: 0273 664501. Fax: 0273600182 or Dr J-H Oddou, B.P. 8, 05000 Gap, France. Fax: (33) 92519255.

Postgraduate course ingynecologic and obstetric pathology with clinical correlation

\section{March 27-31 1995}

The Departments of Pathology, Massachusetts General Hospital and Brigham and Women's Hospital, Harvard Medical School will present a postgraduate course in Gynecologic and Obstetric Pathology under the direction of Drs Robert E Scully, Robert H Young, and Christopher P Crum, to be held at the Four Seasons Hotel, Boston.

This course is designed for pathologists and obstetricians/gynecologists at resident and practitioner levels. It will provide an in-depth review of gynecologic and obstetric pathology with emphasis on morphologic diagnostic features and clinicopathologic correlation including management. Special attention will be paid to recent advances and newly recognised entities. Instruction will be primarily by lecture, but will also include case presentations and discussion periods. Each participant will receive a comprehensive course syllabus.

The course has Category 1 accreditation for approximately 35 hours CME credit by the American Medical Association and 35 cognates, formal learning, by the American College of Obstetricians and Gynecologists. The fee for the course is $\$ 775.00$ (residents and fellows $\$ 600.00)$. For further information, please contact: Department of Continuing Education, Harvard Medical School, 25 Shattuck Street, Boston, MA 02115 (Tel: 617 432 1525; fax 617432 1562).

\section{Melanoma \\ 10-12 May 1995}

Conference Centre, Brighton, UK

The Melanoma Study Group are holding a three day multidisciplinary conference on all aspects of melanoma diagnosis and treatment. The programme includes slide seminars given by a number of experts in the field. A wide range of biopsy material will be available for examination. Abstracts for oral or poster presentation and biopsy cases for discussion are invited. The conference will be suitable for 15 cognate points for $\mathrm{CME}$ and takes place during the Brighton International Festival.

Apply to: Dr N Kirkham, P.O. Box 334, Histopathology Department, Royal Sussex County Hospital, Brighton BN2 5BG. Tel: 0273 664501. Fax: 0273600182.

\section{Correction}

In the October issue of the journal a printing error occurred in the paper by Ohsawa $\mathrm{M}$, Kanno $\mathrm{H}$, Machii T, Aozasa K ( 7 Clin Pathol 1994;47:928-932). Figure 1 was labelled incorrectly as (A), (B), (A) but should read (A), (B), (C). The correct version of fig $1 \mathrm{C}$ is reproduced here.

Figure 1 Monocytoid cells near the sheath artery of the spleen $(A)$ haematoxylin and eosin. Monocytoid cells showing a positive reaction for $C D 20$ (B), but not for DBA.44 (C) (ABC method).

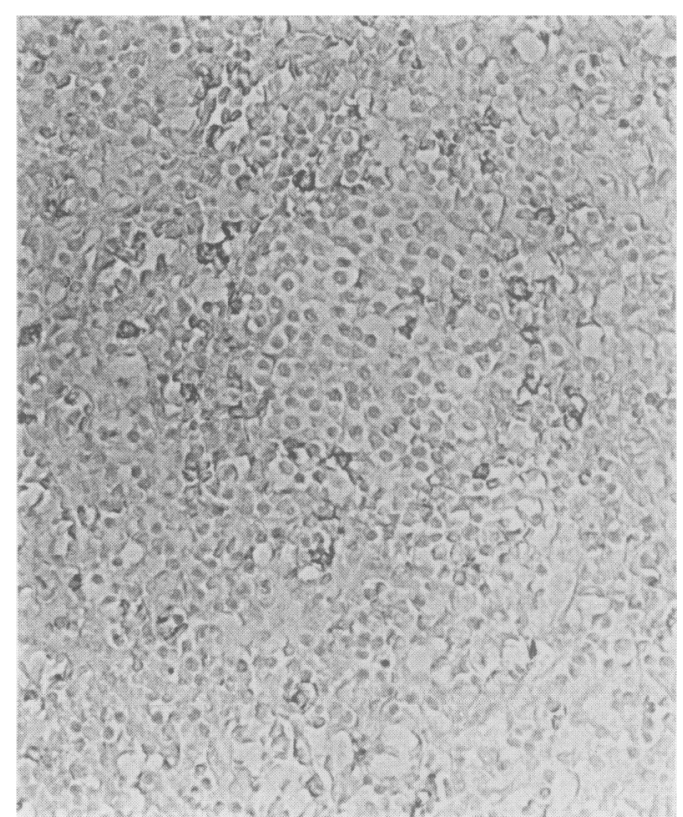

